Review Article

\title{
THE ROLE AND POTENTIAL OF INFORMATION TECHNOLOGY IN AGRICULTURAL IMPROVEMENT
}

\author{
Slavoljub Milovanovic ${ }^{1}$
}

\begin{abstract}
Summary
The agro-industrial sector in developing countries-is faced with challenges, such as requirement for increase of food production and yield and creation of opportunity for employment of rural and poor population. In addition, the agricultural sector is influenced by global factors and fast changes. These facts indicate that there is great need for information and information technologies (IT), which can be used to cope with the challenges and changes and to improve agricultural production and marketing. However, the potential of IT is not fully utilized-in agriculture. Implementation of IT in agricultural sector and rural areas is relatively slow in comparison to the other sectors of the economy where contemporary IT has been implemented at high speed. The aim of the paper is to analyze role, potential and contribution of IT in agribusiness and to explain opportunities for use of IT in many fields of agricultural sector. Our findings are based on economic theory and available literature, and they suggest that IT has great potential for supporting farmers and the other stakeholders in improvement of efficiency, effectiveness and productivity of agriculture. However, the stakeholders have to cope with many limitations and problems in IT implementation and use.
\end{abstract}

Key words: Information and communication technologies, agriculture improvement, agribusiness electronic commerce.

JEL: $M 15, Q 10$

\section{Introduction}

Agriculture plays a significant role for economic and social development in most undeveloped countries. Reasons for this include issues of food security and health of people, requirement for increasing yields and food quality improvement. Challenges in agricultural-development of every country are great, not only because of fulfilment of increasing demand for food, but because of poverty and malnutrition reduction. Issues are also made more complex as agricultural sector development should be achieved on sustainable manner considering natural environment protection.

1 Professor, Ph.D., University of Nis, The Faculty of Economics in Nis, Trg Kralja Aleksandra 11, 18000 Niš, Phone: +381 6432273 82, E-mail: smilovan@,eknfak.ni.ac.rs

EP 2014 (61) 2 (471-485) 
Currently farmers are faced with narrowing profit margins - costs of many inputs like fertilizers and fuel have increased, while product prices have remained fairly constant or even dropped. Increased globalization and market deregulation increase pressures on many smallholder farmers in developing countries. In order to use full effect of these global changes, politics of agricultural products pricing, marketing and trade must be revisited. At the same time, mechanisms for technology transfer must be revisited and revitalized under changed conditions.

In previous decades, significant transformation of agricultural sector is happened. In past, agriculture was driven by bid, but today it is driven by demand. However, we may say that agriculture will be driven by information in the future. New information have to reach endusers very fast in order to use potential opportunities and achieve benefits. Information on seed, water, nutrients and plant protection is one of the main factors for successful farming. Information-intensive and precise techniques of farming based on knowledge are going to be lead factors of sustainable agricultural production. Consequently, farmers should be aware of benefits from internet and the other information and communication technologies (ICT) giving information services that are significant for management of agricultural production. The economic potential of ICT use in agriculture is not fully utilized. Examples include precision farming and livestock management where ICT could facilitate more efficient decision making not only for managers of enterprises related to agriculture, but also for policy makers (Kaaya, 1999; Phougat, 2006).

The potential contribution of ICT to agriculture can be viewed through cost reduction, increase of efficiency and productivity improvement. Foremost, information requirements of farmers should be analyzed and documented and then adequate information systems (IS) should be developed. In development of the systems, focus is on new challenges made from deregulation and globalization of agricultural sector (Samah et al., 2009).

Our review of issues of two worlds (The European Review of Agricultural Economics and The American Journal of Agricultural Economics) and one national agricultural journal (Economics of Agriculture) in last five years shows that implementation and use of ICT as a topic is very rare. In these issues, two papers treat accounting (Zoranović, Vukoje, 2008) and statistical (Odeh et al., 2010) software that can be used in agriculture and two papers (Roe et al., 2011; Diekmann et al., 2008) analyze use of internet auctions in trade of agricultural inputs and outputs. On the other hand, there are IT journals dealing with IT influence on economy and society that also treat IT support to agriculture. The journals mostly publish articles studying implementation and expansion of digital networks in agricultural and rural areas (Blattman et al., 2003; Nicholas, 2003; Ramírez; 2007; Press, 2005; Díaz, Urquhart, 2009).

Obviously, there is gap between requirement for research of role and potential of ICT in agriculture and number of published research papers on the theme. Motivation of this review paper is to reduce the gap, particularly in the Balkan academic research environment. Implications of the research are on farmers, policymakers and researchers. Farmers could get useful knowledge and information about potentials of ICT in management of their crops 
and livestock. Policymakers with responsibility of agriculture improvement could get ideas about methods of facilitating implementation of ISs in agricultural sector. Finally, researchers should have conceptual framework for deep investigation of specific contributions of ICT to agriculture improvement and specific problems in ICT implementation and use.

As mentioned earlier, this paper aims to give a theoretical contribution in study of ICT role and potential in providing of information support to the agricultural sector with specific focus on e-commerce in agribusiness, and limitations in ICT implementation, and elimination of the limitations. In order to meet this aim, the paper is structured in six parts. After introductory remarks, information basis of agricultural production is presented. In the third part of paper, direct and indirect contributions of ICT to agriculture improvement are analyzed in brief while ICT use in EU agriculture is presented in the fourth part of paper. Possibilities of internet technology use in electronic commerce of agricultural products are explained in the fifth part of paper. The sixth part of paper deals with limitations in implementation of ICT in agricultural sector and possible solutions for the problems. In the last part of paper, conclusions related to ICT use in agriculture are presented.

\section{Information support to agricultural production and marketing}

Information of adequate quality is necessary condition for improvement of all areas of agriculture. The importance of information is particularly high in countries on the verge of entering larger markets. This is for example the case for many Balkan and former communist countries in Eastern Europe where accession to the European Union is an issue. Agriculture in these countries is faced with deregulation that represents logical implication of process of integration to European Union which reinforces need for timely and relevant information, in order to make decisions in agricultural sector and the other sectors related with it as suppliers of inputs for it or as buyers of agricultural products and raw materials.

Improved communication and access to information are directly related to the socioeconomic development of every country. Agribusiness is a economic area that has great potential for ICT use in aim of social and economic development of agricultural population (community) and rural regions. However, farmers still have problems to get important information in form that is understandable for them in order to make timely decisions for agricultural production improvement. With improved evidence of data, detailed analysis of costs and sophisticated marketing strategies, farmers will be able to make better decisions and greater profits. In addition, implementation and use of ICT can significantly support increase of competitiveness of theirs husbandries (Cecchini, Scott, 2003; Courtright, 2004).

In order to improve agricultural production, farmers should have following information:

Information on crops - Following information from field can be collected and transferred via internet in database server: categories of seeded crops, size of land with specific crops, time of dropping seed, time of harvest, yields etc. The information is analyzed to create statistical reviews and tables that can be accessed by farmers through internet with ordinary web browser. Farmers can make their own production plans based on the information. 
Information on production techniques developed by experimental agricultural institutes and stations for agriculture improvement can be collected and integrated. The information is made available to farmers through internet and the other channels.

Information on production equipment and agricultural inputs - The information is gathered from enterprises selling equipment for soil processing and other production equipment, seed and the other agricultural inputs. Information collected in such way is offered to farmers.

Market information - In order to support farmers in gaining the best prices for their products, information on market of various agricultural products should be created. Aims of market information activities are to show review of prices on various markets and to facilitate reorientation of farmers' production to markets where better prices are expected. Farmers need overall reviews of food market information. The reviews present valuable information on some most important import and export markets. IT can support to provide forecast information on main agricultural products in subsequent years. Such information helps farmers and traders to make decisions when and how to sell their products (do they sell just after harvest or do they store products in expecting higher season prices). In combination with the other data (for example, available budget of the farm enterprise) such information can be used for decision making about crops which should be produced in next season.

The other information of interest for farmers and their families - Examples of such information includes weather forecast, availability of credit, and expert advice about maintaining crops in healthy state, etc.

There is no doubt that improved information flow has positive effect on the agricultural sector and individual producers, but gathering and distribution of information is difficult and expensive activity. ICT offers capability for increase quantity of information that is available to all stakeholders in agricultural sector and for reduction of information distribution costs to all interested users. ICT can obtain the information to farmers, even when they are in remote places.

Farmers need ICT applications supporting operative aspects of agricultural production for increase of productivity (applications for real-time decision making based on broadband wireless internet, e-mail and chat applications enriched with pictures, video clips and sounds, etc.). These applications are going to play great role in operative management of agricultural production in future. A good example of ICT use for agriculture improvement is mobile communications. This ICT is used as a tool for access to market information (prices), weather forecast, advice of agricultural experts, etc. Today, it is most accessible technology that is available to great number of people including marginalized people in remote, rural areas. All these technological changes give advantage to farmers in creation of effective and inexpensive agricultural production and marketing programs and give opportunity for reduction of poverty and improvement of their life quality (Gorla, 2009). 


\section{Contribution of ICT to improvement of agricultural sector}

The potential of ICT in agricultural sector can be used on two ways: 1. directly, where ICT is used as a tool that contributes directly to productivity of agricultural production, and 2. indirectly, where ICT is used as a tool that provides information to farmers for making quality decisions in efficient management of their enterprises.

Direct contribution of ICT to agricultural production - Precise farming that is popular in developed countries is based on intensive use of ICT and it contributes directly to agricultural productivity. In order to increase agricultural production, techniques of remote sensors with support of satellite technology, geographic information systems (GIS), agronomics and soil science are applied. ICT supports farmers to track and react to weather condition changes on daily basis. Meteorological stations on field supplied with solar energy can be connected to computers of farmers in order to send information on current temperature of air and soil, rainfall, relative humidity of air, moisture of leaf, moisture of soil, length of day, speed of wind and solar radiation. All these techniques and technologies of precise farming require great capital investments which are payable for big farms. They are appropriate for corporate farming while they are less suitable and efficient for small enterprises and farms.

Indirect contribution of ICT to agricultural production - Indirect benefits of ICT are manifested in enabling of farmers for decision making and should be realized in the future development of agriculture. Farmers need timely and reliable sources of information that is explained in previous section of paper. Presently, farmers depend on conventional sources of information that are unreliable and do not give timely information. Changes in the agricultural environment that farmers face make information not only useful but necessary for them to stay competitive and survive on globalized market.

However, efforts on providing of the information will be wasteful if farmers are not able to use ICT. In order farmers to use internet services for searching useful information and communication, elementary computing literacy is required. Through internet, they can track prices and communicate with colleagues around world as often as they want. They can exchange ideas, ask questions and get answers on specific themes. Of specific importance is receiving advices from researchers and agronomists on cultivation of crops and animals. ICT influences on reduction of gap between agricultural researchers and farmers that leads to high developed agriculture having enormous contribution to national economy and society.

\section{ICT use in agricultural sector of $\mathbf{E U}$}

Detailed statistical data about ICT use and contribution to the agricultural sector in EU and Serbia is hardly available. However available the country reports relating agricultural firms and farmers shows that internet access is different from country to 
country in range between 20 and $95 \%$. Statistical data shows that in January 2009 in average $93 \%$ of all enterprises in the EU had access to internet. Mobile internet connections were used by $28 \%$ of all agricultural firms in the EU. The lowest percent of mobile internet connections is in Greece, Cyprus and Romania (Smihily, Storm, 2010).

Considering the basic level of access to mobile communication infrastructure, the usage of mobile phones and even smart phones (with web applications) is high and it is expected to increase extremely in the coming years. Statistical data (Smihily, Storm, 2010) shows that more than $90 \%$ of farmers using mobile devices in countries like Italy, Ireland, Spain but percent of internet access by PC in those countries is relatively low. In these countries, mobile devices are more used as cell phones for call and SMS communication than for mobile applications supporting business transactions based on data communication. Expert estimate the usage of mobile application for business purposes between $2-5 \%$ in these countries.

Precision farming (PF) can be used as measure of farm automation. PF is implemented to a small extent by farmers in the most EU countries. PF and use Geospatial data are only in experimental (research) phase in some developed EU countries. There is a important difference in countries across Europe (for example, Western and North Europe). The case of Czech Republic is good example of progress in PF development. Manufacturers of agricultural machines are the key promoters of implementation of PF techniques in developed countries such as Germany, Denmark, Netherland and Finland (Teye et al., 2012).

In many countries in Europe data integration at intra-enterprise and inter-enterprise level is very weak. The availability and accessibility of (broadband) internet in rural areas is an issue in most countries. There are unions or bodies who take care of the organization of dataflow or data standardization in some countries like Germany, France, Denmark, Belgium and Netherland, but some countries do not have these bodies. Collaboration between private and public organizations to advanced ICT infrastructure is low in countries such as Slovakia, Romania, Lithuania and Czech Republic.

ICT development and use is critical issue because of lack of young people in agriculture. It is case in European countries such as Slovakia, Bulgaria, Italy and others. Countries having many small and probably poor farmers have some problems in the capabilities of investing in farm automation. Some countries with fast growing agricultural sector such as the Baltic States have high potentials referring the implementation of new ICT infrastructure because they have not legacy of old systems and infrastructures. Availability of broadband internet in rural areas is very often mentioned as a main factor influencing ICT development and use in agriculture. A summary of the level of ICT and agricultural technology development and use in some of the EU countries and Switzerland is presented in Table 1. 
Table 1. Level of ICT and agricultural technology use in the EU countries and Switzerland

\begin{tabular}{|c|c|c|c|c|c|c|c|c|}
\hline Country & $\begin{array}{c}\text { Farm } \\
\text { PC }\end{array}$ & $\begin{array}{c}\text { Inter- } \\
\text { net }\end{array}$ & $\begin{array}{c}\text { Farm } \\
\text { Info. } \\
\text { Sys. }\end{array}$ & Phone & $\begin{array}{c}\text { LPIS rele- } \\
\text { vance }\end{array}$ & $\begin{array}{c}\text { Geo- } \\
\text { fertilizing }\end{array}$ & $\begin{array}{c}\text { Animal } \\
\text { registra- } \\
\text { tion }\end{array}$ & $\begin{array}{c}\text { Data } \\
\text { Exchange } \\
\text { Level of } \\
\text { Develop. }\end{array}$ \\
\hline BGR & Low & Low & Low & - & Average & - & - & Hardly any \\
\hline CZE & High & High & High & Low & Average & Average & - & Averagely \\
\hline DNK & High & High & - & High & High & Average & High & Well \\
\hline EST & High & High & Ave-rage & - & Average & Low & Average & Poorly \\
\hline FIN & High & High & High & High & High & Average & High & Well \\
\hline FRA & High & Ave-rage & Ave-rage & High & High & Average & High & Well \\
\hline HUN & Ave-rage & Ave-rage & Low & Low & Average & Low & Average & Poorly \\
\hline ITA & Ave-rage & Low & Ave-rage & Ave-rage & Average & Average & High & Average \\
\hline LVA & Low & High & Low & - & Average & Low & High & Poorly \\
\hline NLD & High & High & High & High & High & Average & High & Well \\
\hline POL & Ave-rage & Ave-rage & Ave-rage & - & Average & Low & Average & Hardly any \\
\hline ROM & Low & Low & Low & Low & Average & - & Average & Hardly any \\
\hline SVK & High & Ave-rage & Low & Low & Average & Low & Average & Poorly \\
\hline SVN & Low & Low & Low & Low & Average & - & Average & Poorly \\
\hline ESP & High & - & Ave-rage & Low & High & Low & High & Averagely \\
\hline SWE & High & - & - & High & High & Low & High & - \\
\hline CHE & High & Ave-rage & Ave-rage & Low & Average & Low & High & Averagely \\
\hline
\end{tabular}

Source: Teye et al., 2012.

\section{Electronic commerce in agricultural sector}

ICT gives opportunity to farmers to extend their market and to gain new customers through the Internet. The Internet improves communication and creates business opportunities for agricultural communities which in the past have operated in relative isolation in remote rural areas. Farmers, researchers, cooperatives, suppliers and buyers can use internet to exchange ideas and information and to govern business as well. Machinery, chemicals and the other types of agricultural inputs can be bought and sold electronically. People can search for jobs and employers can seek new workers through internet (Henderson et al., 2006)

The internet appears to have two roles in agribusiness: as a market venue and as a new source of information. Many internet applications are developed by various interested groups. Applications related to electronic markets can be categorized from farmers' point of view according to following areas: 1. production factors and inputs, 2 services and 3 outputs. Services, production factors and inputs can be provided mainly through internet by fixed prices, while outputs usually can be sold on auctions. This is because many outputs are perishable products, so market prices are sensitive to changes in bid and demand (Cloete, Doens, 2008; Manouselis et al., 2009).

Production factors and inputs - This application area is related to internet sites through which buyers and suppliers can trade by all things of importance to agriculture, such as land, chemicals for plant protection, agricultural equipment and machinery and fertilizers. 
Services - This area of internet use relates to web sites offering electronic services related to logistics, transport and warehousing. The other services that are offered to farmers are: financial services (lending money), insurance services, legal services (advices) etc.

Outputs - As we already mentioned, application on the output side are usually in form of electronic auctions. Some of these typical applications are related to auction web sites for trade by cattle, hay, fish and special market products such as vine and nuts.

Internet applications that are information-oriented can be categorized by following areas: providing information, management tools and liaison with regulatory bodies.

Providing information - This service concerns-obtaining information content from following sources: electronic agricultural magazines, web sites offering market information and analyses, on-line weather reports and recommendations of agricultural experts.

Management tools - These are on-line tools including calculators, data base tools, tools for specific information tracking, analytical tools and electronic forms. Examples for calculators are: calculator of profitability in production of veal, calculator of milk quotas, calculator of loans and credits. Tools for information tracking and analysis can be found in accounting application packets. Also, representative data base applications can be found on data base software markets.

Liaison with regulatory bodies - Many web sites obtain links to regulatory bodies that create official publications, reports, official pronouncement for media, etc. Examples for typical regulatory bodies are: Ministry of agriculture, European Commission, OECD, World Trade Organization, etc.

Therefore, as the Internet becomes popular among people dealing with agribusiness, more and more it is becoming basis for electronic commerce (e-commerce) with agricultural products and inputs for agricultural production. Participation in e-commerce implies that buyers and vendors are able to effectively use adequate software and hardware. In e-commerce, transactions between agricultural enterprises (B2B -Business-to-Business) are more prevalent in comparison with transactions between agricultural enterprises and individual farmers (B2C -Business-to-Consumer). Reasons for such state in agricultural e-commerce are lower acceptance of new ICT and internet by farmers. In next section, we are going to explain in more details reasons for low acceptance and use of ICT in agricultural sector.

\section{Limitations in implementation of ICT and possible solutions}

Except the great potential that ICT has in improvement of agriculture, there are some limitations that can make implementation and expansion of ICT in agricultural sector difficult. Some researches (Rao, 2003; Mittal, 2012) explain factors and limitations preventing effective implementation and use of ICT in agricultural sector and rural areas. These limitations include:

Lack of awareness about benefits of ICT - Many people in rural areas have no-computer and internet access. This contributes to their lack of awareness of the benefits from using 
ICT. On the other side, providers of ICT and policymakers are sceptical about ability and willingness of the rural population to accept and use of ICT. As a result, there are small number of projects that improve implementation and use of ICT in agricultural sector and rural areas.

Uncoordinated and chaotic development of systems - If we take into account huge volume of work related to information systems (IS) development for improvement of agriculture, coordination mechanism in form of specialized agency should be created. Aim of the agency is to concentrate efforts on support to agricultural community. Such coordination agency can have only consultative role in following areas: user interface, overall design of system, mechanism for content delivery and standards for setting of information kiosks.

Easiness of system use and language barriers - Success of strategy of ICT implementation in agriculture depends on easiness of system use by rural population. In many instances, ISs supporting agriculture are not easy to use and there is lack of appropriate internet information contents suitable to needs and abilities of rural population. This requires intuitive presentations based on graphics. In addition, touch screen information kiosks should be installed in order to encourage greater participation of rural population in using of ISs. Moreover, there is a language barrier for large segments of the rural population to use systems. In order to solve this-problem, commands of applications should be translated to native language and fonts for native language and mechanism for content synchronization should be installed.

Connectivity - Cost of computers and fees for internet access are still high for the most rural population that is poor in developing countries. In addition, availability of internet access is low in rural areas because Internet Service Providers (ISP) delivers services mainly in urban centres. Although great advancement is made in several past years, connectivity in rural areas should be improved. Reliable network connection is prerequisite for successful implementation of ICT in rural areas. Many private ISPs have installed huge networks connecting great cities and towns. As these networks are going through rural areas, it is possible to provide connectivity for great number of villages. There are several technologies to make connectivity in remote rural areas without fixed telephone network. Presently, cellular telephone network appears as the most appropriate wireless medium for connection of remotest villages while satellite technology is very expensive.

Bandwidth of network - Even where telephone and the other communication services exist, available bandwidth can be limitation for effective use of networks. Whereas internet services for rural and agricultural areas require intensive use of graphics, low bandwidth of network can be main limitation for providing of electronic services to farmers. Storage of static information in kiosks and transfer dynamic information from remote locations could be solution for the limitation.

Points for information distribution - Massive use of information kiosks is critical for effective use of internet contents and services. Such kiosks should be designed as electronic supermarkets. In addition to serving as information sources these kiosks provide, other services to people who live in rural areas including distance learning, training, rural e-mail centre, chat sessions with experts, and e-government. Government can obtain financial 
support for unemployed graduates of agronomy who live in rural areas who could play role of efficient liaison with low educated rural users of systems. Aims of these actions should be transformation of rural information kiosks to communication gateways for farmers and the other rural population.

Idea of engaging unemployed graduates of agronomy as liaisons and instructors for low educated rural users of systems is presented by Mittal, but is not further developed by the other researchers. In spite of scarce public funds and budgets in the time of economic crisis, the government could obtain time limited sponsorship of firms that employ unemployed graduates to make ICT use expands. After this limited time period firms employing these graduates would decide whether to keep these graduates or not. However this time period can be used for implementation of the most needed applications which provide increased profitability for both farmers/farm enterprises and for firms employing these graduates. Profitability of such applications and systems would provide venture capital, and make it possible to gradually phase out government financial supports to these firms. In addition, great number of poor educated farmers would get opportunity to acquire knowledge and skills for ICT use.

Responsibility for implementation of ISs in agricultural sector - Collective and coordinated effort of many stakeholders is necessity for creation of specialized web sites and portals in agriculture. This task is so great that it cannot be done by only one institution and organization. Main stakeholders in the agricultural sector such as the fertilizer or food industries should join effort in achieving of the task. As already mentioned, government can initiate creation of coordination agency where various stakeholders join efforts in expansion of computing culture in rural areas and in same time gain benefits from efficient operations taking place in computing environment. Various stakeholders should create appropriate private-public partnership (PPP) in order to improve coordination and collaboration.

Creation of effective private-public partnership - There are numerous experiences of PPP creation in domain of ICT implementation in agricultural sector that are presented in literature (Kazlauskiene, Meyers; Twaakyondo et al., 2002; Gakuru et al., 2009; Brewster et al., 2012; McNamara et al., 2011; Qiang et al., 2012). For example, the EU's Future Internet PublicPrivate Partnership (FI-PPP) program is directed to use of Future Internet technologies in order to make service infrastructures more efficient and intelligent. The SmartAgriFood is one of the eight projects in FI-PPP program that treats applying ICT to three sub-domains: agricultural production ("Smart Farming"), the transportation sector ("Smart Agri-logistics") and improving food awareness for consumers ("Smart Food Awareness"). The project is currently in the phase of developing pilot implementations since user requirements are successfully gathered and analysed (Brewster et al., 2012).

Partnerships among organizations with different specialties, capacities, and profit motives are appropriate way to implementation of ICT in agriculture. Enabling such partnerships and maintaining them is a main government role. PPPs provide a framework for governments to exploit the synergies between the public and private competences and to access the funds and skills needed for ICT implementation. A major strength of the private sector is in 
achieving cost-benefit analysis of ICT projects that is usually driven by the profit motive. On the other side, public sector has motive and ability to finance ICT projects that provide public goods such as access to government information. The public sector expresses great interest in ICT as a mean for providing better public services significant to agriculture such as land registration, forest management, and collection of agricultural statistical data. Private sector engagement can enhance the access, affordability, and adaptability of ICT for agriculture development. Many other development projects suffer from lack of public funds and private interest but development projects concerning ICT have benefited from growing private sector interest and public demand (McNamara et al., 2011).

PPPs were first created for infrastructure projects where the private sector had insufficient funds and the public sector had insufficient skills to manage. The attitude that PPPs are significant only for infrastructure is based on numerous successful infrastructure projects supported by PPPs. However governments realized soon that PPPs can also be used to develop applications and services. The motive to use PPPs in areas besides infrastructure became stronger as governments experienced great public deficits. The entrepreneurial nature of ICT attracts new partnerships and forms of investment. Software design, development of mobile phone applications and mentioned local language customization represent the opportunities for continued innovation supported by PPPs. Private firms providing applications are often interested in working with the public sector in order to offer their technology products and services to smallholders.

However, problem with PPPs in developing countries is in poor planning, design, and measurement as well as unclear goals. Hence public and private stakeholders interested in PPPs must have sufficient capacity for creation and managing this kind of partnership (Qiang et al., 2012).

Lack of motivation to use computers and internet - Despite internet access, users in rural areas have to be motivated for internet use. In order to use internet, farmers and the other individuals in rural areas must have adequate level of competence and skills. Besides explained engagement of unemployed rural agricultural graduates as computer educators in rural areas, the other methods of computer literacy improvement of farmers could be used. For example, a group of farmers can install a computer with internet connection and any educated young man from that group can experience training in using computer and internet tools. He can help his colleagues to acquire computer knowledge and skills and to increase motivation to use computers and internet (Phougat, 2006). Key challenge in adoption of these methods of farmers' education is to motivate young and educated people to stay in rural areas. General suggestion (Kazlauskiene, Meyers) for governments in retaining and attracting people to rural areas is to make incentives and conditions for development of services of general interest, such as accessibility (roads, railways, waterways), ICT (broadband access, e-services, e-health, etc.), and public services (water, waste treatment, energy, health, education, etc.)

Lack of online government information - Much of potentially vital government information is not available online. Governments in many developing countries do 
not focus on the poor population in rural areas and do not give them appropriate information and services through internet that could be used for improvement and development of agriculture.

\section{Conclusion}

Farmers and policymakers working on improvement of agriculture should be able for effective use of ICT, in order to react to new conditions which are characterized by: complete and partial deregulation of agricultural market, reduction of protectionist measures of government, opening of agricultural markets, fluctuations in agricultural environment and use of chances for export. Quality of rural life also can be improved by quality information enabling better decision making. ICT can play a main role in support of transformation of rural areas and agriculture in order to respond to these challenges and reduce digital inequality and divide between rural and urban areas.

Fast changes in ICT domain enable development and dissemination of electronic services in agriculture. National strategies for implementation and use of ICT in agriculture should be formulated. National coordination agencies with consultative role can act as catalyst in this formulation process. No single institution can alone successfully implement ICT in agriculture and rural areas. Therefore, industries with great influence on agriculture, like the fertilizer or food industry, should jointly initiate and encourage implementation of ICT in agriculture.

\section{References}

1. Blattman, C., Jensen, R., Roman, R. (2003): Assessing the Need and Potential of Community Networking for Development in Rural India, Information Society, Vol. 19, Issue 5, pp. 349-364.

2. Brewster, C., Wolfert, S., Sundmaeker, H. (2012): Identifying the ICT Challengesof the Agri-Food Sector to Define the Architectural Requirements for a Future Internet Core Platform, Proceedings of eChallenges e-2012 Conference, Paul Cunningham and Miriam Cunningham (Eds) IIMC International Information Management Corporation, pp. 1-8.

3. Cecchini, S., Scott, C. (2003): Can Information and Communications Technology Applications Contribute to Poverty Reduction? Lessons from Rural India, Information Technology for Development, Vol. 10, Issue 2, pp. 73-84.

4. Cloete, E., Doens, M. (2008): B2B E-marketplace Adoption in South African Agriculture, Information Technology for Development, Vol. 14, Issue 3, pp. 184-196.

5. Courtright, C. (2004): Which Lessons Are Learned? Best Practices and World Bank Rural Telecommunications Policy, Information Society, Vol. 20, Issue 5, pp. 345-356.

6. Díaz, A. A. E., Urquhart, C. (2009): The value of Extended Networks: Social Capital in an ICT Intervention in Rural Peru, Information Technology for Development, Vol. 15, Issue 2, pp. 108-132. 
7. Diekmann, F., Roe, B. E., Batte, M. T. (2008): Tractors on eBay: Differences between Internet and In-Person Auctions, The American Journal of Agricultural Economics, Vol. 90, Issue 2, pp. 306-320.

8. Gakuru, M., Winters, K., Stepman, F. (2009): Innovative Farmer Advisory Services Using ICT, Proceedings of IST-Africa 2009 Conference, P. Cunningham, M. Cunningham (Eds.) IIMC International Information Management Corporation, Available at: http://ist-africa. org/Conference2009/outbox/ISTAfrica_Paper ref 85 doc 2692.pdf

9. Gorla, N. (2009): A Survey of Rural e-Government Projects in India: Status and Benefits, Information Technology for Development, Vol. 15, Issue 1, pp. 52-58.

10. Henderson, J. R., Akridge, J. T., Dooley, F. J. (2006): Internet and e-Commerce Use by Agribusiness Firms: 2004, Journal of Agribusiness, Vol. 24, Issue 1, pp. 17-39.

11. Kaaya, J. (1999): Role of Information Technology in Agriculture, Proceedings of FoA Conference, Vol. 4, pp. 315-328.

12. Kazlauskiene, N., Meyers, W. H., Financing Rural Development in Central and Eastern Europe: Opportunities and Constraints, Available at: http://portal.zzbaco.com/mojo baco/Data/Sites/1/docs/mono/EAAE/A/17\%20SA\%20Kazlauskiene Natalija.pdf

13. Manouselis, N., Konstantas, A., Palavitsinis, N., Costopoulou, C., Sideridis, A.B. (2009): A Survey of Greek Agricultural E-Markets, Agricultural Economics Review, Vol. 10, No. 1, pp. 97- 112.

14. McNamara, K., Belden, C., Kelly, T, Pehu, E., Donovan, K. (2011): ICT in agricultural development, ICT in Agriculture - Connecting Smallholders to Knowledge, Networks, and Institutions, The International Bank for Reconstruction and Development/The World Bank, Washington, pp. 3-14.

15. Mittal, S.C. (2012): Role of Information Technology in Agriculture and its Scope in India, Available at: http://125.19.12.220/applications/Brihaspat.nsf/6dca49b7264f71ce 65256a81003ad1cb/82f2c15ccd4dd9a065256b37001af3fe/\$FILE/it fai.pdf

16. Nicholas, K. (2003): Geo-Policy Barriers and Rural Internet Access: The Regulatory Role in Constructing the Digital Divide, Information Society, Vol. 19, Issue 4, pp. 287-295.

17. Odeh, O. O., Featherstone, A. M., Bergtold, J. S. (2010): Reliability of Statistical Software, The American Journal of Agricultural Economics, Vol. 92, Issue 5, pp. 1472-1489.

18. Phougat, S. (2006): Role of Information Technology in Agriculture, Science Tech Entrepreneur, August, pp. 1-7.

19. Press, L. (2005): Toward a Global Rural Network: Strategy and Action Plan, Information Technology for Development, Vol. 11, Issue 4, pp. 399-405.

20. Qiang, C. Z., Kuek, S. C., Dymond, A., Esselaar, S. (2012): Mobile Applications for Agriculture and Rural Development, ICT Sector Unit World Bank, Washington, pp. 56.

21.Ramírez, R. (2007): Appreciating the Contribution of Broadband ICT With Rural and Remote Communities: Stepping Stones Toward an Alternative Paradigm, Information Society, Vol. 23, Issue 2, pp. 85-94. 
22.Rao, S.S. (2003): Information Systems in Indian Rural Communities, Journal of Computer Information Systems, Vol. 44, Issue 1, pp. 48-56.

23. Roe, B. E., Wyszynski, T. E., Olimov, J. M. (2011): Pigs in Cyberspace: A Natural Experiment Testing Differences between Online and Offline Club-Pig Auctions; The American Journal of Agricultural Economics, Vol. 93, Issue 5, pp. 1278-1291.

24.Samah, B.A., Shaffril, H.A.M., Hassan, M.D.S., Hassan, M.A., Ismail, N. (2009): Contribution of Information and Communication Technology in Increasing Agrobased Entrepreneurs Productivity in Malaysia, Journal of Agriculture \& Social Sciences, Vol. 5, No. 3, pp. 93-97.

25. Smihily, M, Storm, H. (2010): ICT Usage in Enterprises 2009, Eurostat: Data in focus 1/2010. Available at: www.tporganics.eu/upload/TPOrganics ImplementationActionPlan.pdf

26. Teye, F., Holster, H., Pesonen, L., Horakova, S. (2012): Current Situation on Data Exchange in Agriculture in EU27 and Switzerland, ICT for Agriculture, Rural Development and Environment, T., Mildorf, C., Charvat, Jr. (Eds), Czech Centre for Science and Society Wirelessinfo, Prague, pp. 37-47.

27. Twaakyondo, H. M., Bhalalusesa, E. P., Ndalichako, J. L. (2002): Factors Shaping Successful Public Private Partnership in the ICT Sector in Developing Countries - The Case of Tanzania, Available at: http://tanzaniagateway.org/docs/ICT_sector_in developing_countries_the_case_of_Tanzania.pdf

28.Zoranović, T., Vukoje, V. (2008): Softver za mala poljoprivredna gazdinstva, Ekonomika poljoprivrede, vol. 55, br. 3, IEP Beograd, str. 329-338. 


\title{
ULOGA I POTENCIJAL INFORMACIONE TEHNOLOGIJE U UNAPREĐENJU POLJOPRIVREDE
}

\author{
Slavoljub Milovanović ${ }^{2}$
}

\section{Rezime}

Agroindustrijski sektor u svakoj zemlji u razvoju je suočen sa izazovima, kao što su zahtevi za povećanjem proizvodnje hrane i prinosa i stvaranje šansi za zapošljavanje ruralnog $i$ siromašnog stanovništva. Osim toga, poljoprivredni sektor je pod uticajem globalnih faktora i brzih promena. Ove činjenice pokazuju da postoji velika potreba za informacijama $i$ informacionim tehnologijama (IT) koje se mogu iskoristiti u borbi sa ovim izazovima $i$ promenama i u unapređenju poljoprivredne proizvodnje i marketinga. Međutim, potencijal IT nije u potpunosti iskorišćen u poljoprivredi. Implementacija i širenje IT u poljoprivrednom sektoru i ruralnim oblastima se odvijaju relativno sporo u poređenju sa drugim sektorima ekonomije gde se savremene IT implementiraju velikom brzinom. Cilj ovog rada je da analizira ulogu, potencijal i doprinos IT u unapređenju abrobiznisa $i$ da objasni mogućnosti korišćenja IT u mnogim oblastima poljoprivrednog sektora. Metod teorijske analize istraživanja koja su vođena na ovu temu je iskorišćen u ovom radu. Rezultati prezentirani u ovom radu pokazuju da IT ima veliki potencijal za podršku farmerima i drugim subjektima u unapređenju efikasnosti, efektivnosti i produktivnosti poljoprivrede. Međutim, svi subjekti uključeni u poljoprivrednu proizvodnju moraju da savladaju mnoga ograničenja i probleme u implementaciji i korišćenju IT.

Ključne reči: informaciono-komunikacione tehnologije, unapređenje poljoprivrede, elektronska trgovina u agrobiznisu.

2 Prof. dr Slavoljub Milovanović, Univerzitet u Nisu, Ekonomski fakultet, Trg Kralja Aleksandra 11, 18000 Niš, Telefon: +381 6432273 82, E-mail: $\underline{\text { smilovan@eknfak.ni.ac.rs }}$ 